\title{
La administración en época de pandemia
}

\section{Por. Jorge Zelaya Cobos}

Lic. en Administración de Empresas.

Especialista en el área del Talento Humano

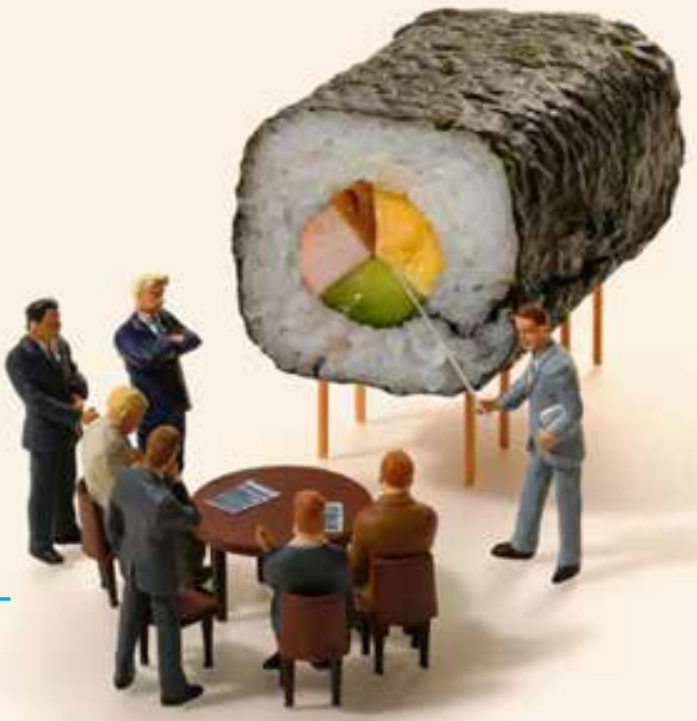

Desde los albores de la industrialización y de los padres de la administración, Taylor y Fayol, el proceso administrativo se ha convertido en una piedra angular en el desarrollo de cualquier tipo de empresa. Reyes Ponce, lo retoma y hasta nuestros días, con cuatro, cinco o seis elementos, forma parte de la razón de ser de la administración de empresas.

No importa el tamaño de la empresa, (nano hasta mega empresas) los CEO tanto de primera línea, como en la toma de decisiones, encuentran en el proceso administrativo una guía a seguir para el manejo acertado de un negocio. Serán una serie de habilidades blandas, las que llevaran a obtener la eficiencia y eficacia necesaria para subsistir en un mercado cada día más competitivo y cambiante.

Al respecto, nos enfrentamos a una época de cambios acelerados que ha traído como consecuencia la pandemia del COVID-19. Y debemos responder a estas interrogantes:

- ¿Han cambiado las empresas en su organización?

- ¿Se ha modificado el mercado al que atendemos?

- ¿Que se necesita para adaptarnos a los cambios impuestos?

- ¿Seguirá creciendo la economía post pandemia?

Obviamente las empresas han experimentado cambios en su organización, desde el momento en que modificaron sus horarios de trabajo, se implementó el teletrabajo masivo y físicamente se han tenido que modificar las instalaciones, haciéndolas más seguras para evitar el contagio del virus aun latente. Ha existido un replanteo de metas y objetivos, debiendo priorizar en las vitales y postergar las secundarias 0 colaterales.

La forma de realizar el marketing, sin duda alguna, ha incrementado "el delivery" o servicio a domicilio en vista que mucha gente prefiere no salir de su casa y realizar la mayoría de transacciones desde su hogar, por lo tanto, han nacido más pequeñas empresas que se dedican a la venta y distribución de comestibles. Lo que parecía un caos al principio, se ha visto como una gran oportunidad para algunos emprendedores emergentes y otros, han incrementado su volumen de venta, a lo mejor diversificando su producción. El Whatsapp se ha vuelto casi indispensable, pues muchos pequeños empresarios ahí se anuncian sin costo alguno, realizando las ventas de la misma forma.

De igual manera, las campañas publicitarias, están orientadas a permanecer más en sus casas disfrutando en familia y procurando un trato preferencial para las personas de la tercera edad, tratando de concientizar a la población a seguir adelante, pero tomando todas las medidas necesarias para protegernos.

Difícilmente, por ahora, se pueden hacer campañas de ofertas que atraigan a multitudes, así que, los encargados de publicidad deberán implementar medidas y promociones que estimulen la compra, pero de otra forma. No dudo que los creativos, muy pronto nos sorprenderán con las grandes ofertas por la época navideña. 
Muy oportuno podría ser la realización de una pequeña investigación de mercados, que arroje datos fehacientes acerca de las preferencias de los consumidores en la neo realidad. No llevaría mucho tiempo y no requiere de muchos recursos, ya que se puede realizar por internet.

Un libro tan elemental como ¿Quién se comió mi queso? Nos relata una fábula interesante de cómo enfrentarse a los cambios, cual es nuestra actitud cuando se ha terminado ese delicioso queso que solíamos comer. Por lo tanto, la empresa debe ser proactiva y reactiva al mismo tiempo. Así muchas empresas nuestras, se han adaptado y siguen haciéndolo, a esos cambios que impone la nueva normalidad. Tienen que observar los protocolos de higiene, el número de personas que se atienden, tomar temperatura, ofrecer gel para las manos, alfombras desinfectantes, en fin, una serie de detalles que anteriormente parecían irrelevantes, pero ahora son vitales para seguir compitiendo en el mercado.

Como en todo proceso de cambio, habrá personas que se adapten rápidamente a esta nueva situación y otros que nunca se adaptarán, lo cual no es muy saludable para su estabilidad laboral y pudiera acarrear una serie de frustraciones e incremento del stress post pandemia.

Los Gerentes de Recursos Humanos, continuarán en la búsqueda de esos talentos necesarios para impulsar la maquinaria empresarial, sin embargo, sus procesos de selección deben ser revisados, pues ahora, se necesitaran más personas ALFAS o sea, que sean pensantes, propositivos, tenaces, resilientes, dinámicos, creativos y analíticos. Por otro lado, deberán garantizarle estabilidad al personal existente, lo que incide directamente en un buen clima laboral que continúe permitiendo el desarrollo integral del ser humano y el incremento de su productividad. Así mismo, los programas de capacitación deberán tener muy en cuenta los cambios cuantitativos y cualitativos que ha experimentado la sociedad en general, para continuar preparando a su personal, de cara al futuro.

La nueva normalidad, representa muchos retos en un estadio de mucha inseguridad, pero donde los consumidores no abandonan sus hábitos de consumo que deben ser satisfechos, así como, nos enfrentamos al nacimiento de demandas de productos que antes no se consideraban de primera necesidad, como por ejemplo, las laptops que cada estudiante debe poseer para recibir sus clases a distancia, servicios de televisión y cable, en vista que las personas socializan menos fuera de casa, etc.

Es momento que todas las áreas de la empresa, innoven sistemas, procesos, productos, envoltorios y todo aquello que se adapte a las prácticas actuales. Deberá existir una coordinación cuidadosa y una excelente comunicación, a fin de responder rápidamente a las necesidades del consumidor final. De vital importancia es, no descontextualizarnos, esto sería ignorar que ha sido el año 2020 el que ha marcado un cambio radical en el mercado internacional, en el mercado local y la forma de cómo hacer negocios. Los consumidores progresivamente han internalizado temores, se han visto expuestos a cuarentenas como nunca, los que a muchos a descompensado en mayor o menor grado y buscan empresas que de alguna manera les hagan sentir seguros con la prestación de sus productos o servicios.

Alicia Bárcenas, directora de la CEPAL, quien ha sorprendido con su liderazgo durante esta pandemia, en sus declaraciones de agosto/20 señaló que América Latina, durante el primer y segundo trimestres ha incrementado el teletrabajo en $324 \%$ y la educación a distancia en más del $60 \%$; aunque el crecimiento de la región aparece en números rojos, en vista del cierre de muchas empresas. Esto nos orienta sobre lo que está sucediendo en nuestro país en cuanto a crecimiento económico, al menos durante este año.

Hoy más que nunca, debería existir mucha flexibilidad en la organización, hacer una revisión de políticas y reglas, de manera tal, que permitan a sus ejecutivos atender a este mercado en evolución y no seguir con prácticas tradicionales.

Debemos ser optimistas y contribuir según nuestra experticia a que las empresas sigan vivas, quizás reinventándose, pero sin prescindir del activo más valioso de la organización: los recursos humanos, y que estas experiencias que estamos viviendo nos permitan obtener una retroalimentación que nos conduzca a fortificarnos y continuar por el camino del éxito, aunque este se encuentre en el mediano y largo plazo. 